\title{
FOREIGN POLICY OF JAPAN
}

Khalil-ur-Rehman Shaikh*

\section{Abstract}

In post war era, Japan emerged as a pacifist country. The constitution of Japan restrained from developing armed forces for offensive but permitted only for defensive purpose. Thus, Japan raised Self Defense Force. This posture greatly contributed in its emergence as world economic power. In post-cold war period, Japan appeared with advanced step in its foreign policy and sent its forces abroad as a part of UN Peace Keeping Force abroad. It little questioned the objective of creating SDF. 9/11 incidents changed the global politics. Japanese citizens also fall prey to it. Japan joined coalition on War on Terror and helped to fight against terrorism. In post 9/11, Japan has improved its relations with China despite territorial dispute. However, it plays its role in global political, economic, cultural and strategic areas.

Keywords: Cold war, Nuclear, ODA, Phases, Terrorism,

\section{INTRODUCTION}

The western powers' occupation of different countries in Asia mostly continued until the Second World War. The Portuguese, Dutch and the English etc. competed for colonizing the countries. The locals in Asia generally refused to accept the colonization. The resistance against the western colonialism in Asia gave birth to the idea that Asian affairs should be left to Asia to determine a type of Asian Monroe Doctrine- and the notion that Japan should bear primary responsibility for leading Asia in achieving this, became a central pillar of Japanese diplomacy in the period from the end of the [nineteenth] century to the World War-II (Kazu, 2015).

*Research Scholar and Analyst. Email: rahmank28@yahoo.com (Corresponding author) 
The end of the War changed the outlook of the external affairs of Japan. The Treaty of Friendship and Security signed between the US and Japan in 1951 and in 1960 laid the second foundation of the foreign policy of the latter. Earlier to this, the constitution of Japan, effected from 1947, paved the way for emergence of Japan's pacifist external policy. During the period of Cold War, the pacifist policydominating factor in Japan's foreign policy-played a vital role international affairs.

The end of the Cold War brought little change in the foreign policy of Japan. In 1992, it decided to send its forces as a part of the United Nations Peace Keeping Forces in Cambodia. It was for the first time that the Japanese forces went beyond its homeland territories and performed. Japan took drastic action and enacted Peace Keeping Operations Law in 1992. The five principles of this law allowed Japan's Self Defense Force to go Cambodia and take part under the flag of the United Nations Peace Keeping Force (Soderberg, 2010).

The 9/11 incident brought radical changes in international relations. It ended the concept of territorial enemy. Invisible enemy got birth, which could attack internally or externally without having formal army and definite location. It brought the global security at risk. Japan was not the exception. Japan timely responded to the call of waging War on Terror. It supported the war on land and shore. Its foreign policy was transformed. However, shadow of the US on Japan's external policy continued, the country also adopted different course of action on its foreign fronts.

\section{LITERATURE REVIEW}

The book 'Japan's Foreign Policy' (Landgon, 1973) has deliberated upon foreign policy of Japan during periods of its Prime Ministers Hayato Ikeda and Eisaku Sato. While discussing on 1960 crisis the author has given basis of increasing cooperation between the US and Japan after World War II, he writes that Japan being isolated from 
many Asian countries and communist control on mainland China, was dependent on the US for export market and source of supply. Cooney (2006) in his book 'Japan's Foreign Policy since 1945' discusses the various phases of Japan's foreign policy. The author discussing the mediating role of the decision processes between Change Agents and Degree Policy Change put light on the account of various authors, who have penned books on foreign policy of Japan.

The book, 'Japan's Foreign Policy in the Twenty First Century' (Er, 2020) contains the articles of various researchers. Part-I of the book pertains to Three pillars of Japanese foreign policy; part II deals with domestic sources of Japanese foreign policy; part-III relates to Japanese diplomacy; and part-IV deliberates upon Japanese old and new regional enactment. In book 'Japanese Asian Diplomacy: A Legacy of Two Millennia' (Kazu, 2015), Asian foreign policies and Japan's likely relations with China and other countries have been discussed. The book discusses the local movements against the colonial powers. The author has examined Japan's relations with China and Korea in the light of its relations with the West.

\section{RESEARCH METHODOLOGY}

This is a pure qualitative research study, which is based on secondary source. Various books and articles on the subject of foreign policy in general and foreign policy of Japan were critically analysed. In the light of collected secondary material, following two research questions were addressed:

- Has Japan supported international efforts against terrorism?

- $\quad$ Has The US-Japan Security Treaty benefitted both?

\section{FINDINGS AND DISCUSSION}

\section{Japan's foreign policy}


Beginning of an initiative starts with setting goals and objectives. Every country also sets its objectives to deal with its internal and external affairs. These objectives are aimed at protecting a country internally and securing interests abroad. In the beginning, objective of Japan's foreign policy was to have alliance with the West through the US and maintain its Asian identity. Japan got success in its objective, but the various factors including Japan-US alliance kept Asia divided into mainly two blocs. First, pro-American countries and other was the Soviet bloc.

The objectives of foreign policy of Japan have background of sufferings caused at the end of the World War II. Its objectives include promoting peace, protecting its territorial integrity and sovereignty and futuristic approach to deal with the challenges etc. Japan has the following three main objectives of its foreign policy:

\section{Prosperity of the global economy}

Japan plays important role in addressing the issues of poverty and famine. It started program of Official Development Assistance (ODA). The objectives of the assistance program are to contribute to the peace and development of the international community, and thereby to help ensure Japan's own security and prosperity (MoFA, 2003).

\section{To promote world peace and stability}

Japan learnt lessons from catastrophe of nuclear attacks by the US on Hiroshima and Nagasaki on $6^{\text {th }}$ and $9^{\text {th }}$ August, 1945 respectively. It renounced war. Article 9 of the Constitution 1947 of the country provides:

Aspiring sincerely to an international peace based on justice and order, the Japanese people forever renounce war as a sovereign right of the nation and the threat or use of force as means of settling international disputes. In order to accomplish the aim of the preceding paragraph, land, sea, and 
air forces, as well as other war potential, will never be maintained. The right of belligerency of the state will not be recognized (Government of Japan, 1947).

Thus, Japan developed Self Defense Force (SDF). Japan joined multilateral organizations to support regional and international efforts for promoting peace. It extended the hand of cooperation to the United Nations High Commissioner for Refugees (UNHCR) for alleviating the sufferings of the refugees. It has played its due role in promoting peace efforts in the United Nations.

The nuclear arsenals and armament has kept the world on boiling point. The nuclear race in the regions of South Asia, the Korean peninsula, the Middle East (Israel) and the nuclear competition between the US and Russia etc. is threat to the global peace.

Japan is signatory to Nuclear Non-proliferation Treaty. It has denounced efforts of getting nuclear might. It holds nuclear program of North Korea as threat to its security. North Korea has developed nuclear program mainly probably due to presence of the US forces on the soil of Japan.

In May 1998, India and Pakistan conducted atomic explosions. Japan condemned the action and held Kashmir as a flash point. In other words, the problem of Kashmir between Pakistan and India may cause nuclear war between the two adversaries.

\section{Address international issues}

The country is dealing with various issues at regional and international levels. These included but not limited to nuclear armament, terrorism, poverty, maritime affairs, pollution, climate change and assistance to displaced persons etc. Japan not only has maintained a fair and objective assessment on the international situation, but also has possessed her own independent viewpoint. To hold a constantly fair and objective assessment and carry out dialogue 
with countries is not only a way for Japan to contribute politically to the international community but also a way to enhance its international status (JIIA, 1984, p, 29).

Japan advocates for 'Atom for Peace'. It has been playing its role for disarmament and non-proliferation. Moreover, it calls all the countries having nuclear weapons towards nuclear disarmament while increasing transparency in military arrangements.

The Great Britain paved the way for the creation of Jewish state on the land of Palestine through Balfour Declaration. The Palestinians have still been struggling for their separate homeland. Japan supported the right of self-determination of the Palestinians.

In 2017, the US President Donald Trump announced his decision of shifting his country's embassy from Tel Aviv, capital of Israel, to Jerusalem. International community condemned the US decision. Peculiarity of such condemnation was that even allied countries of the US including Japan also criticized the US.

Pakistan and other countries jointly moved a resolution against the US decision in the United Nations General Assembly. It was adopted by 128 votes in favor and 9 in against. Japan also supported the resolution. It indicates that Japan may also vote against its 68 years old ally in future.

\section{Phases of foreign policy}

The foreign policy of Japan has passed through the different phases. Modern foreign policy change in Japan contains three major periods. These include the opening of Japan and the Meiji era up to World War- II, the Cold War and now the cold war time (Cooney, 2006, p23). Broadly, phases of the foreign policy may be divided into cold war period (1945 to 1991), post-cold war period (1991-2001) and post 9/11 period. 


\section{Cold war period}

Japan remained under occupation of the United States since its surrender in 1945. Japan signed Peace Treaty on $8^{\text {th }}$ September, 1951, thus, occupation came to an end on $28^{\text {th }}$ April, 1952. The Prime Minister of Japan, Shigery Yoshida signed the Treaty.

Earlier to Korean War Japan supplied goods to the US from the beginning of the war. The US forces, stationed on the soil of Japan, became a staging point for military personnel into Korea.

The cold war era was dominated by the US and the erstwhile Soviet Union (now known as Russian Federation), to extend their respective sphere of influence in nook and corner of the world. The world was mainly divided into two blocs i.e. the capitalist and the communist. The continents were divided on the basis of ideology. Eastern Europe emerged in the continent of Europe comprising countries under the influence of the communist super power.

Japan remained in the US camp throughout the period of cold war. It pursued its security goals chiefly with the cooperation of the United States, its great power ally. Policy of security cooperation was implemented through the security treaties of 1951 and 1960 which paved the way for lending military bases to the US for its guarantee of Japan's defense (Landgon, 1973). Due to three main concerns against Japan, the planners of the United States designed unequal treaty. Firstly, Japan might remilitarize after occupation and launch a revanchist attack. Secondly, due to instability it might require excessive US attention. Thirdly, Japan might conclude separate peace with communist powers and they might get access to its considerable industrial potential (Samuels, 2008). The leaders of Japan depended exclusively on the United States to maintain military balance at regional level and pursue for economic recovery (Shiela, 2019).

Other main causes of Japan's remaining in the US camp were due to the following factors: 
Firstly, the World War-II was fought between allied and axis powers. The US, the Soviet Union and other countries formed former group whereas Japan joined the latter group. This historical group formation restrained the US and the Soviet Union from coming closer to each other.

Secondly, Japan is ally of the western bloc through Treaty of Mutual Cooperation and Friendship in 1952. The US is responsible for its defense.

Thirdly, communist revolution took place in China in 1949. Two communist countries in Asia strengthened the expectations of the communist countries due to likely increase in their influence. It also contributed towards presence of Japan in the western camp. Fourthly, the Soviet Union was economically weak in comparison to the US and other western countries. War torn country required economic development. The countries of the western bloc could fulfill this need of Japan.

Fifthly, Japan and the Soviet Union has dispute on Kurile Islands. Japan needed support of the countries, outside the communist camp, at global and regional forums. The United Nations Security Council has five permanent members i.e. the US, the Soviet Union, China, the United Kingdom and France. Out of five members, three were part and parcel of the US led bloc. Such majority could favor Japan on the dispute. Tens of thousands of people of China took to streets between $2^{\text {nd }}$ April to 17th April 2005 in Chingdu, Beijing, Shangai, Guanzzhou and elsewhere against Japan's bid for a permanent seat on the United Nations Security Council (Zhang, 2007).

Sixthly, the Soviet Union had motto of exporting communist ideology to nook and corner of the world. Japan has remained predominated capitalist country. The capitalist theory is entirely contrary to the communist ideology. Contrast between the two ideologies kept Japan away from the Soviet Union. 
Lastly, Japan has remained under the Kingship, which is contrary to the rule by one party. The institution of the kingship found traces in Before Christ era. After the enforcement of the constitution in Japan the office of the King became ceremonial. The people of Japan refused to discontinue their historical ruling institution. Thus, it was impossible to bring the Kingship to an end by permitting the communist ideology on their homeland.

Japan sustained two setbacks in its relations with the US. The US without informing its ally sent Henry Kissinger, foreign minister, to visit China in 1970. It began an era of rapprochement between the US and China. It paved the way for visit of the US President to China. It was reported that Nixon [then US President] had three aims in visiting Peking, in addition to political considerations for the presidential elections of November 1972. They were (1) to open dialogue between the US and China (2) to diminish the possibility of the Soviet Union's pre-emptive strike against China before the latter's development of nuclear weapons and (3) to obtain the cooperation of China in an honorable US withdrawal from Vietnam (JIIA, 1973).

In 1973, the Organization of Arab Petroleum Exporting Countries (OPEC) imposed oil embargo on the US. It also created difficult situation for Japan. It was first encounter of Japan with the Middle East but did not affect it militarily (Cooney, 2002). Japan is dependent on the Persian Gulf countries for its oil requirements. It fulfils about $80 \%$ of its oil needs from the countries of the Middle East. Thus, Japan could not afford adverse or strained relations with these countries. It decided to deal the Middle Eastern countries beyond the US approach. Japan succeeded in its diplomacy.

During the period of cold war, Japan pursued for having permanent seat in the Security Council of the United Nations. Japan sent state ministers and parliamentary vice-ministers for foreign affairs to different regions for mustering support for a permanent seat. 
Last years of the cold war period witnessed the Soviet invasion of Afghanistan on 29th December, 1979. It threatened international peace. The move also put the interests of the US and its allies in jeopardy. Landing of the Soviet troops in Afghanistan tended to put Japan's own interest in jeopardy (Malik, 2009). Japan condemned the Soviet action. It extended support to Pakistan. The displaced Afghans received Japanese aid through the United Nations High Commissioner for Refugees. It supported the Indirect Talks between Pakistan and Afghanistan under the auspices of the United Nations for withdrawal of the Soviet forces from Afghanistan.

Japan supported the resolutions moved in the UN General Assembly for evacuation of Afghanistan by the Soviet forces. Tokyo, on $7^{\text {th }}$ January 1980, announced three prong policy. Firstly, it supported Security Council Resolution for withdrawal of the Soviet forces from the occupied country. Secondly, Japan reviewed the exports of computers and other high technology items. Thirdly, the Government of Japan would suspend official dealings with Moscow. The Soviet Union and Japan have dispute on Kurile Islands. The invasion of Afghanistan further aggravated the situation and relations of both the countries went low. The Prime Minister of Japan, Ohira announced that his country would not participate in the Summer Olympics due to the Soviet presence in Afghanistan (Yoshitzu, 1981).

\section{Post-cold war era}

The Soviet Union lost its territorial integrity in late 1991. Consequently, cold war ended. The change in international political, economic and military dynamics did not much affect the foreign policy patterns of Japan. Domestic and environmental policies dominate bilateral and multilateral relations. This factor also exists in Japan's relations with the United States or Europe or Russia. Indeed, it survives in the case of Japan's security arrangements with the US and issue of Okinawa ((Kazu, 2015). However, it experienced some changes. These included the following: 
Firstly, alliance between Japan and the US continued. The United States' forces remained stationed on the soil of Japan. However, the communist threat disappeared.

Secondly, the Soviet Union disappeared. Thus, the threat of super power on back of dispute on Kurile Islands diminished to some extent.

Thirdly, North Korea is a communist country. The defunct Soviet Union supported it in the region. North Korea had launched its nuclear programme, which Japan held as a threat to its security. However, this programme has been continuing but support of the Soviet Union ended. It probably paved the way for Japan to face North Korea without fear of the communist super power.

Fourthly, North Korea continued its nuclear program. Thus, worries of Japan remained alive. Fifthly, the disintegration of the Soviet Union opened the way for making Asian fraternity strengthened. However, regional and bilateral issues between the Asian countries lost chances of such dream. Japan, being a part of Asia continent, could not play desired role in this regard.

Lastly, the Central Asian Republics got independence after the disunion of the communist super power. The region is plenty of natural resources. Japan being a deficient in natural resources has interests in the region. It wants engagement with the regional countries to take benefit of energy reserves of the region. Japan is making attempt to enlarge its oil supplies from the region of the Middle East and from Russia's Sakhalin and Southeast Asia liquefied natural gas (LNG). It makes the Central Asia with abundance of oil and natural gas reserves (Chung, 2014).

\section{9/11 and beyond}

The terrorist attacks on the US on $11^{\text {th }}$ September, 2001 reshaped the global politics. It provided the world with an enemy who might attack 
a target while sitting inside its territory. Invisible striker may target a place of one's own choice. It left the world insecure. The public of Japan expressed reaction with alarm and shock and extended support to its ally, the United States (Midford, 2006).

Japan faced acts of terrorism. Japan Red Army attacked the targets having interest of Japan. Various incidents took place. These included but not limited to attacks on train, nerve gas attack in subway in Tokyo in 1995 and bomb attack at high school in Ikeda in 2000. However, Japan got control over such terrorist attacks.

The US announced War on Terror against the terrorists. Japan condemned the 9/11 incident and readily decided to join the WoT. The then Prime Minister of Japan, Junichiro Koizumi announced his following policy to combat terrorism:

- Japan will actively engage itself in combating the terrorism, which it regards as its security issue;

- Japan strongly supports its ally [the US] and will act in concert with the US and other countries around the world;

- Japan will take concrete and effective measures clearly demonstrating its firm determination. These measures will be implemented in a swift and comprehensive manner;

The parliament of Japan, Diet, passed Anti-Terrorism Special Measures Law in October 2001. It permitted Japan's SDF to extend rear-area support to the United States and other countries participating in WoT (Kliman, 2006). Japan announced to extend refueling facility to the war ships participating in the war. It was done under Operation Enduring Freedom-Operation Interdict Maritime (OEF-OIM).

Afghanistan is central to the western countries and Japan for their interests in the region of Central Asia. The Gwadar seaport located in Balochistan province of Pakistan is the nearest water access to supply natural resources of the region to outside world. To reach Gwadar the 
location of Afghanistan is important. The US has been in Afghanistan since the initiation of WoT in 2001.

The global situation got new birth when the world learnt about the China Pakistan Economic Corridor. It is a part of the One Belt One Road initiative of China. Pakistan and China have invited other countries to participate in the initiative and take maximum benefit out of it.

The US and other countries including Japan seem apprehensive on CPEC. However, encouraging sign is that despite number of issues between China and Japan both countries are making efforts to improve their bilateral relations. The meetings between the two countries from ministerial level to the summit are proof of this notion.

In response to Belt Road Initiative (BRI), the US, Japan, India and Australia are pursuing 'Indo-Pacific Initiative'. 'Free and Open IndoPacific' strategy, put forwarded by Japan, has got momentum. Shinzo Abe, premier of Japan articulated this concept in 2007. Later on, it was picked up by the US and other countries.

Japan is determined not to follow the road of becoming a big military power, although, it is economically capable of doing so. This is so to speak, a challenging experiment unprecedented in history. Many difficulties are to lie ahead since Japan has chosen-such a unique way of life and to overcome them and to move forward. It must continue to persist in its firm determination and rally the wisdoms and efforts of the whole nation.

\section{CONCLUSION}

Japan has various challenges on front of its external relations. Experience and future strategy may help Japan to meet these challenges. It may keep changing patterns of international political, economic and strategic order in view to get success in its foreign relations. It is concluded that Japan may revisit its Security Arrangements with the United States as scope of Self Defense Force 
is increasing with passage of time. Further, Japan may resolve their outstanding issues with China \& Russian Federation amicably as it may muster support for Japan for pursue of permanent seat in the UN Security Council. Asian fraternity may be strengthened and consolidated. However, it must not base on hatred with world outside Asian continent.

\section{REFERENCES}

Chung, C. P. (2014). Contentious integration: Post-cold war Japan-China relations in the Asia-Pacific. Burlington: Ashgate Publishing Limited.

Cooney, K. (2006). Japan's foreign policy since 1945. New York: M.E. Sharpe Armank.

Cooney, K. (2002). Japan's foreign policy maturation: A quest for normalcy. New York: Routledge Taylor \& Francis Group.

Er. L.P. (2020). Tokyo's quest for a United Nations Security Council permanent seat. In L.P. Er \& P. Jain (Eds.) Japan's foreign policy in the twenty first century. (pp. 37-54) Maryland: Lexington Books.

Government of Japan (1947.) The Constitution of Japan. Retrieved from https://japan.kantei.go.jp/constitution_and_ government_of_japan/constitution_e.html

Japan, MoFA (2003). Japan's Official Development Assistance Charter. Retrieved from https://www.mofa.go.jp/policy/oda/ reform/revision0308.pdf

JIIA. (1973). White Papers of Japan 1971-72, 1973. Tokyo: The Japan Institute of International Affairs.

JIIA. (1984). White Papers of Japan 1982-83, 1984. Tokyo: The Japan Institute of International Affairs.

Kliman, D. M. (2006). Japan's security strategy in the Post 9/11 World: Embracing a New Realpolitik (Vol. 183). Greenwood Publishing 


\section{Group.}

Landgon, F. C. (1973). Japan's foreign policy. Vancouver: University of British Colombia Press.

Malik, R. A. (2009). Pakistan-Japan relations: Continuity and change in economic relations and security interests. London: Routledge Taylor \& Francis Group.

Midford, P. (2006). Rethinking Japanese public opinion and security: From pacifism to realism. Stanford: Stanford University Press.

Ogura, K., \& Noble, D. (2015). Japanese Asian Diplomacy: A legacy of two millennia. Tokyo: International House of Japan, Inc.

Samuels, R. J. (2008). Securing Japan: Tokyo's grant strategy and the future of East Asia. London: Cornell University Press.

Shiela, S. A. (2019). Japan rearmed: The politics of military power. Harvard University Press.

Soderberg, M. (2010). Foreign aid as a tool for peace building: Is the goal security or poverty reduction. In M. Soderberg \& P. A. Nelson (Eds.). Japan's politics and economy: perspectives on change (pp. 99-116). New York: Routledge Taylor \& Francis.

Yoshitsu. M. M. (1981). Iran and Afghanistan in Japanese perspective. Asian Survey, XXXI (5), 501-514.

Zhang, J. (2007). The influence of Chinese nationalism on SinoJapanese relations. In H. Michael \& N. Night (Eds.). ChinaJapan relations in the twenty first century creating a Future (pp.1534). Cheltenham: Edward Elgar. 